\author{
Piotr Fiedorczyk \\ University of Bialystok, Poland \\ ORCID: 0000-0001-5456-0394 \\ fiedorczyk@uwb.edu.pl
}

Anna Stawarska-Rippel

University of Silesia in Katowice, Poland

ORCID: 0000-0003-3252-9171

anna.stawarska-rippel@us.edu.pl

\title{
On the Possibility of Acquisitive Prescription by the State of Real Properties Unlawfully Seized under the Provisions of the 1944 Agrarian Reform Decree
}

\author{
O możliwości zasiedzenia przez Skarb Państwa nieruchomości \\ bezprawnie przejętych na mocy przepisów dekretu z 1944 r. \\ o reformie rolnej
}

\begin{abstract}
The subject of this paper are those factual states that occurred on the basis of the agrarian reform decree and concerned the unlawful seizure by the State of palace-park complexes. It was only after the collapse of real socialism in 1989 that the owners or their legal successors obtained an annulment of the decision to seize the property. However, this was, and is, only the beginning of the struggle, as the State Treasury or its legal successors are claiming before the common courts the acquisitive prescription of the property being the subject to the recovery claim. The divergence of at least 20 years in jurisprudence as to the date of commencement of the period required for acquisitive prescription (1980-1991) is an undesirable phenomenon, requiring the adoption of a coherent approach of the courts. Consequently, the authors of this text represent the view that the period of validity of both the Agrarian Reform Decree and the subsequent legal acts, with particular emphasis on the period of
\end{abstract}

CORRESPONDENCE ADDRESS: Piotr Fiedorczyk, PhD, Dr. habil., Professor of the University, Faculty of Law, University of Bialystok, Mickiewicza 1, 15-213 Bialystok, Poland; Anna Stawarska-Rippel, PhD, Dr. habil., Professor of the University, Institute of Law, Faculty of Law and Administration, University of Silesia in Katowice, Bankowa 11b, 40-007 Katowice, Poland. 
validity of the Decree of 1945 (Journal of Laws no. 28, item 321) and then Article 9 (16) of the Act of 1958 excluded the course of the acquisitive prescription in favour of the State Treasury of the agricultural and forestry properties unlawfully seized by the State. This period lasted until 31 December 1991, i.e. until the final date when Article 9 (16) was in force.

Keywords: acquisitive prescription of the property; agrarian reform; palace-park complexes; State Treasury; property; Agrarian Reform Decree

\section{INTRODUCTION}

The agrarian reform, which in the Supreme Court's opinion juridical closure ${ }^{1}$ happened together with coming into force of the Act of 12 March 1958 on the sale of state-owned agricultural property and on the regulation of certain matters related to the implementation of agrarian reform and agricultural settlement, ${ }^{2}$ was initiated during the time of warfare and implemented quickly in order to cover the largest possible area of real estate. This haste caused "stumblings" in the decree law, which were eliminated on an ongoing basis through amendments, court rulings and informal guidelines issued by the new authorities. Carrying out the agricultural reconstruction in a planned and uniform manner had, in the opinion of the Supreme Court, a "thoroughly revolutionary character", which required "concentration of the whole action in the hands of the administrative bodies appointed to carry out the reform and agricultural settlement with simultaneous elimination of interference in these matters by other bodies, among others courts". ${ }^{3}$ The principle of non-interference of the courts in all civil cases, even if only very indirectly related to the agrarian reform, found later a detailed justification in the resolution of the panel of 7 judges of the Supreme Court of 13 October 1951: "The actions of the administrative authorities are thus conceived as a planned action implementing in an orderly manner the great objective envisaged by the agrarian reform. This action, by its very design, could produce positive results only if it remained solely in the hands of the appointed authorities and did not suffer any interference from factors outside the sphere of the competent administrative authorities, and in particular of the judicial authorities. The authorities appointed to carry out the Agrarian Reform Decree would not be able to fulfill their task properly if the courts, by their decisions, could overturn their orders and thus destroy the basis on which the whole

1 J. Majorowicz, Przebudowa ustroju rolnego Polski Ludowej w orzecznictwie Sądu Najwyższego, [in:] Sesja dwudziestolecia Sądu Najwyższego w Polsce Ludowej w dniach 8-10 grudnia 1966 r. Materiaty, Warszawa 1967, p. 156, 201.

2 Journal of Laws 19858, no. 17, item 71, as amended.

3 J. Majorowicz, op. cit., p. 157. 
plan of their activity was built". ${ }^{4}$ In the context, therefore, of the real purpose of the so-called agrarian reform, the effective redress by the owners of the seized properties was illusory.

The expropriation action was intended to cover and in fact covered a much larger range of property than provided for in the 1944 Agrarian Reform Decree, and its course was suited to taking over a coppice, a cardboard factory as well as a quarry, which was facilitated by the intersecting premises of the nationalization acts, and by the manipulation of the concept of land property, also after amending the Agrarian Reform Decree (17 January 1945). ${ }^{5}$ Initially, the Ministry of Agriculture and Agrarian Reforms requested the adoption of a definition that land property is any property located outside the administrative boundaries of cities, instead of the one based on the criterion of productive usefulness. Subsequently, the Ministry of Agriculture and Agrarian Reforms, in a letter to the Presidium of the Voivodeship National Council of 13 November 1950, explained: "In executing Article 2 of the Decree of 6 September 1944 on the implementation of the agrarian reform, the term 'land property' means not only property located outside the administrative boundaries of a city, but also property located within the administrative boundaries of a city if it has an agricultural character". ${ }^{6}$

Nowadays, there should be no doubt that both the Polish Committee of National Liberation (Pol. Polski Komitet Wyzwolenia Narodowego, PKWN; so-called first "people's government"), as well as the Decree of 6 September 1944 on conducting the agrarian reform (Journal of Laws no. 4, item 17) adopted by it, lacked proper legitimacy (constitutional legitimacy). ${ }^{7}$ In particular, the Decree on carrying out the agrarian reform, which provided for such a form of seizing real estate on behalf of the State Treasury, had no basis neither in the March Constitution of $1921,{ }^{8}$

${ }^{4}$ Resolution of the panel of 7 judges of the Supreme Court of 13 October 1951, C 427/51, OSN 1953, no. 1, item 1.

5 A. Machnikowska, Prawo wtasności w Polsce w latach 1944-1981. Studium historycznoprawne, Gdańsk 2010, p. 193.

${ }^{6}$ Archive of Modern Records in Warsaw, Ministry of Agriculture and Agricultural Reforms, ref. no. 446, p. 545.

7 A. Stawarska-Rippel, O ludowym prawie karnym w kontekście przeprowadzenia i zabezpieczenia skutków tak zwanej reformy rolnej z pierwszych lat Polski Ludowej, “Z Dziejów Prawa” 2019, vol. 12(20), pp. 711-713; eadem, O instrumentalnym wykorzystywaniu prawa - ustrój polityczny i gospodarczy w orzecznictwie Sąu Najwyższego pierwszych lat Polski Ludowej, [in:] Prawo i czas. Ksiega jubileuszowa z okazji 80-lecia urodzin Profesora Adama Lityńskiego, eds. M. Borski, D. Fleszer, A. Pokora, A. Rogacka-Łukasik, Sosnowiec 2020, pp. 232-242. Cf. I. Hasińska, Z procesowej problematyki wywtaszczenia na tle dekretu PKWN o przeprowadzeniu reformy rolnej z 6 września 1944 r., "Studia Iuridica Lublinensia" 2017, vol. 26(1), p. 78.

8 The Decree of 6 September 1944 on carrying out the agrarian reform was contrary to the wording of Article 99 of the March Constitution, which provided for the necessity of compensation. On agrarian reform in the Second Republic, see S. Prutis, Reformy agrarne w Polsce po odzyskaniu niepodległości w 1918 roku, "Studia Iuridica Agraria” 2018, vol. 15, pp. 201-216. 
to which basic assumptions of the government of the People (Polish communist authorities) referred to in its propaganda, nor in the April Constitution of 1935. Despite the negative opinion of the then law in the axiological context, as well as the lack of competence to enact it, the Constitutional Tribunal in the decision of 28 November 2001 (SK 5/01) stated the impossibility to control the constitutionality of the agrarian reform. The merit of the decision of the Constitutional Tribunal is inherent in the fundamental dilemmas characteristic for political breakthroughs and accompanying problems concerning the legal continuum. ${ }^{9}$ At the same time, the Constitutional Tribunal indicated that this was a complicated and controversial problem, which was demonstrated by the fact that four judges of the Tribunal submitted separate opinions suggesting that undertaking a merits-based assessment of the Agrarian Reform Decree would not necessarily lead to undermining its legal effects, due to the acquired rights of the beneficiaries of the agrarian reform. As raised in one of the dissenting sentences: "the Court's assessment of the question whether control of the compatibility of the contested provision (Article 2 (1) (e)) with the Constitution is necessary for the protection of constitutional rights and freedoms could be approved if it concerned only real estate which, after its seizure by the State Treasury, had been granted to natural persons under the Agrarian Reform Decree, but no longer when it concerned real estate which continues to constitute state property (Judge Andrzej Mączyński)". ${ }^{10}$ Moreover, the academic dispute, which was cardinal in the context of the political system and civil rights, conducted in the first years of the People's Republic of Poland, as to the scope of the validity of the March Constitution had in fact no practical significance in the realities of the people's state.

The problem of the validity of the March Constitution was present in the jurisprudence of the Supreme Court, although initially the position of the Supreme Court on this issue was not uniform. However, one can observe a gradual (in 1945-1947) evolution of the Supreme Court's view, which eventually led, among other things, to the undermining of the constitutional principle of property protection. " "The revolutionary changes that had taken place in Poland, however, meant that it would not be a return to the old social, legal and state order, that a new social, legal and state system would be established. [...] The old pre-war legal order could not be considered valid. However, the idea that the old legislation had ceased to be valid in its entirety was not accepted, as this would have created a legal vacuum. The

\footnotetext{
9 A. Stawarska-Rippel, Prawo sadowe Polski Ludowej a prawo Drugiej Rzeczypospolitej 1944-1950, Katowice 2006, p. $21 \mathrm{ff}$.

${ }^{10}$ Decision of the Constitutional Tribunal of 28 November 2001, OTK 2001, no. 8, item 266. Cf. G. Tracz, Sytuacja prawna byłych właścicieli nieruchomości ziemskich w III Rzeczypospolitej, "Forum Prawnicze" 2016, no. 4, p. 28.

11 A. Bereza, Sąd Najwyższy w latach 1945-1962. Organizacja i działalność, Warszawa 2012, p. 91.
} 
resulting legal situation was therefore not clear [...] there was a tacit assumption that what was valid from the old legal order was that which was not contrary to the basic assumptions of the new regime". ${ }^{12}$ The political and legal situation in the first years of the People's Republic of Poland was described by M. Mazur, the then president of the Supreme Court, during a session marking the $20^{\text {th }}$ anniversary of the Supreme Court's functioning: "There was no doubt that certain provisions from the interwar period could not be taken over by the new system and had to be discarded. What remained to be decided, however, was the assessment of the specific provision and the form and legal basis for rejecting a provision that had not been expressly repealed. In the eyes of some, certain provisions were even politically unclear, e.g. in the context of the basically correct criticism of formalism and dogmatism, 'excesses' were made, which of course also affected the courts. $[\ldots]$ The jurisprudence of the Supreme Court was not free from these fluctuations either, and it was the Court's duty to shape the practice of the judiciary". ${ }^{13}$

The subject of this paper are the factual states that occurred on the basis of the Agrarian Reform Decree and concerned the seizure of palace-park complexes and sometimes of ordinary houses. It was done unlawfully, also without observing the area norms provided for in the Decree. It was only after the collapse of real socialism that the owners, or their legal successors, obtained an administrative decision that the earlier decision to seize property was invalid. However, this was, and is, only the beginning of the struggle, as the State Treasury or its legal successors invoke before the common courts the acquisitive prescription of the property subject to the restitution claim, usually arguing that the time limit for the declaration of acquisitive prescription had long expired, since it had lasted from the moment the property was taken over in the 1940s. ${ }^{14}$ In this context, it is worth recalling the ruling of the Supreme Court regarding the acquisition of ownership of land by way of acquisitive prescription, in which the Supreme Court, by the resolution of the panel of 7 judges of 7 June 1962, stated that persons who before 13 September 1944 obtained possession of lands constituting part of the land property allocated for the purposes of the agrarian reform, cannot acquire ownership of these lands by way of acquisitive prescription after the date when the Decree of 6 September 1944 on conducting the agrarian reform came into force. In the justification of the resolution, the Supreme Court emphasized that the objectives of the agrarian reform could be materially harmed in specific cases if the ownership of the land included

${ }^{12}$ M. Mazur, Uwagi ogólne o sytuacji prawnej po Wyzwoleniu, [in:] Sesja dwudziestolecia Sąu Najwyższego ..., p. 11.

13 Ibidem, pp. 31-32.

${ }_{14}$ See an exemplary case description in M.P. Stokowski, Odpowiedzialność Skarbu Państwa za przejęcie nieruchomości rolnych na mocy dekretu o przeprowadzeniu reformy rolnej na przykładzie majątku Lubowicz Wielki, "Miscellanea Historico-Iuridica” 2020, vol. 19(2), pp. 383-403. 
in the stock of land designated for the purposes of the agrarian reform could be acquired by way of acquisitive prescription, in respect of which the provisions of the law (Articles 50 to 58 of the Property Law) do not provide for subjective and objective limitations. ${ }^{15}$

This text tries to prove that the period required for acquisitive prescription started much later, i.e. on 1 January 1992. The analysis is also supported by a partial review of the Supreme Court and common courts' cases on this issue.

\section{A FEW REMARKS ON THE ACT OF 12 MARCH 1958}

The fundamental issue for this study is the interpretation of the Act of 12 March 1958 on the sale of state-owned agricultural property and on the regulation of certain matters relating to the implementation of agrarian reform and agricultural settlement. ${ }^{16}$ This Act entered into force on 5 April 1958, and the key provision for this study read: "Article 9: 1. Agricultural and forestry properties, which have been taken over by the State prior to the date of entry into force of this Act, shall be seized by the State irrespective of their area, if they are still in possession of the State or have been transferred by the State for use to other natural or legal persons. These properties shall be seized without compensation, and debts and burdens secured on these properties shall be canceled, with the exception of easements, the maintenance of which shall be recognized as necessary. 2. The provision of para. 1 shall not apply to the land referred to in Article 2 of the Act of 1957 on the repeal of the Decree of 9 February 1953 on the total development of agricultural land (Journal of Laws no. 39, item 173) and the land taken over by the State under the provisions of the Decree of 26 April 1949 on the acquisition and transfer of real property necessary for the implementation of national economic plans (Journal of Laws 1952 no. 4, item 31). 3. The decision to seize agricultural property shall be made by the Agricultural Administrative Body of the Presidium of the District National Council, and the decision to seize forestry property shall be made by the State Forestry Division. A decision on the recognition of an easement shall be made by the authority which is competent to issue a decision on the seizure of real estate for State ownership. 4. Court proceedings for the restoration of possession or for the release of real estate referred to in para. 1 shall get barred by the statute of limitations, and unexecuted enforcement titles adjudicating these claims shall be

15 J. Majorowicz, op. cit., p. 161.

${ }^{16}$ In the recent literature, the Act is partially discussed in A. Korzeniewska-Lasota, Państwo, właściciele i ich spadkobiercy wobec mienia pozostawionego przez obywateli polskich w województwach wschodnich międzywojennej Rzeczypospolitej. Studium historyczno-prawne, Gdańsk 2018, pp. 217-220. 
without legal effect". Of some importance, there was also Article 10, which gave the former owners referred to in Article 9 the right to a senile or disability pension if the conditions set out in that provision were met.

In relation to the amendments, Article 10 ceased to be binding as of 1 January 1968 (Article 127 (4) (6) of the Act of 23 January 1968 on universal pension provision for employees and their families, Journal of Laws 1968, no. 3, item 6). However, in the light of the consolidated text (Journal of Laws 1989, no. 58, item 348) Article 9 was numbered as Article 16 and was then deleted by Article 58 (2) of the Act of 19 October 1991 on the management of agricultural real property of the State Treasury and amendments to certain acts (Journal of Laws 1991, no. 107, item 464). The duration of Article 9 (16) was, therefore, from 5 April 1958 till 31 December 1991.

The literature has already described the mechanism of this provision, which basically meant that any application by an owner for the return of property unlawfully seized under the Agrarian Reform Decree was to result not in the surrender of the property, but in the issuance of a decision on the final seizure of the property by the State. ${ }^{17}$

On the basis of the provisions of Article 9 and the case law of the Supreme Court, the following procedural mechanism emerged. If a party applied to an administrative authority for the return of an agricultural or forest property or for the annulment of rulings made on the basis of the Agrarian Reform Decree or on any other legal basis, then the administrative authority was obliged to issue a decision that the property would be seized by the State. There was also nothing to prevent the administrative authority from initiating proceedings on the seizure ex officio. This could be the case, in particular, when the court, acting pursuant to Article 236d of the Code of Civil Procedure (and in accordance with the guidelines of the judiciary and judicial practice of 27 June 1953) ${ }^{18}$ inquired whether administrative proceedings on the seizure were pending or even merely informed about the action brought by the owner. In the latter situation, the court acted as a kind of denunciator, and its denunciation caused the administrative authority to initiate proceedings ex officio. It then notified the court, which - in accordance with the Supreme Court rulings - suspended the civil proceedings. After the decision to seize the property for state ownership became binding - as there could be no other solution - the court discontinued the proceedings. In this way, the system became impermeable and did not give the owner any chance to regain the property. What is more, taking

17 P. Fiedorczyk, Polski Październik a reforma rolna, “Z Dziejów Prawa” 2019, vol. 12(20), pp. 801-814.

${ }_{18}$ According to the resolution of the entire Civil Chamber of the Supreme Court containing guidelines for justice and judicial practice on the application of Article 236 of the Code of Civil Procedure, and in particular $\S 1$ thereof, the court's power under Article 236 became a duty when it was in the interests of social property. About these guidelines, see A. Stawarska-Rippel, Prawo sadowe..., pp. 98-101. 
any legal action, whether in administrative proceedings or by way of civil action, had to lead to the loss of ownership of the property to the State.

The above leads to one logical conclusion: the owner of an agricultural or forest property unlawfully seized by the State before 5 April 1958 had no chance to regain it after that date - moreover, any legal action taken by him resulted in a definite loss of the ownership right. Such a view was recently expressed by the District Court in Bialystok, when it held that for the owners to apply for the return of the property "would in fact mean requiring them to demand that the then state itself take the property belonging to them".${ }^{19}$ In addition, in this case the state took over the property lege artis, as all the statutory prerequisites were met. Taking legal action by the owners would thus be tantamount to a worsening of their legal position, since from the status of owners unlawfully deprived of possession they became former owners of agricultural or forestry property confiscated or, if you prefer, seized by the state without compensation.

It should be considered whether a possible legal action by the unlawfully deprived owner against the state as the holder of the unlawfully seized real estate did not interrupt the period required for the state to acquire the real estate. The answer to this question is positive - the filing of claims had the effect of interrupting the running of the time-limit required for acquisitive prescription. However, a ruling that the property had been taken over by the state as a result of filing claims made the problem of acquisitive prescription irrelevant, as the state then changed its status from a (self-) proprietor and became the owner. As a consequence, it was impossible to raise the objection of interrupting the period required for acquisitive prescription in the future.

In this context, one can speak of a peculiar legal masterpiece, created by the socialist state thanks to the Act of 12 March 1958 and the judicial decisions developed pursuant to it. Despite various attempts, the communist justice system did not allow any breaches. For example, a linguistic interpretation of the Act's title allowed it to be assumed that the Act only applied to agricultural property seized in connection with agrarian reform and settlement. However, the decision of the Supreme Court of 29 September 1959 clearly accepted that there were no grounds for excluding abandoned properties from the effects of Article 9. "This is not contradicted by the heading of the Act. If a statute regulates many issues, the heading usually, as in the case at hand, mentions only the most important of them" - stated the Supreme Court in its reasoning. ${ }^{20}$ This view was challenged by the Voivodeship Administrative Court in Warsaw only 15 years after the transformation of the political system (IV SA 3240/03), which made it possible to mitigate the negative effects of the 1958 Act to a small extent.

19 Decision of the District Court in Bialystok of 27 April 2018, II Ca 57/18, LEX no. 2505911.

20 Judgement of the Supreme Court of 29 September 1959, 1 CR 689/59, OSN of the Civil Chamber and Criminal Chamber 1960, no. 4, item 108. 


\section{THE CREATION OF THE SUPREME ADMINISTRATIVE COURT AND THE QUESTION OF THE POSSIBILITY OF OBTAINING LEGAL PROTECTION UNDER THE ACT OF 12 MARCH 1958}

It is well known that the Act of 31 January 1980 created the Supreme Administrative Court. To this day the motives behind E. Gierek's team's decision to make this truly revolutionary move for the legal system are unknown. As far as agricultural matters were concerned, particularly high hopes were connected with the administrative judiciary, drawing attention to the unprofessionalism of the then agricultural administration. ${ }^{21}$ These hopes were fulfilled, and from the point of view of the then authorities, the establishment of the administrative judiciary was - from the historical perspective - an action against their interests. An independent administrative judiciary is to this day one of the most important guarantors of the rule of law. This is probably why in many rulings of common courts after 1989 it began to be assumed that the creation of administrative judiciary marked the beginning of judicial control over the legality of administrative decisions, and thus made it possible to effectively pursue claims against administrative bodies, since an administrative decision could be annulled through the courts. The date of the beginning of the Supreme Administrative Court's activities thus became the date which, according to many opinions, marked the end of the suspension of the judiciary in the times of the People's Republic of Poland. The question arises as to whether this date can be applied to claims by citizens for the return of property seized under the agrarian reform and subsequent acts. We believe that the creation of administrative courts changed nothing here. We share here the view recently expressed in the decision of the District Court in Lublin of 14 December 2016: "In the opinion of the Court of Appeal, such a possibility [i.e., recovery of the real estate seized by the State - the palace and park complex] was not given to O.S. [i.e., the plaintiff] also by the establishment in the Polish legal order of the Supreme Administrative Court by the Act of 31 January 1980 on the Supreme Administrative Court and on amendments to the Act - Code of Administrative Procedure (Journal of Laws no. 4, item 8), because the creation of the administrative judiciary was not associated with a change in the politically conditioned interpretation of the provisions of the Decree on carrying out the agrarian reform and, until 1989, there was no possibility for O.S. to recover the properties in question by proving that they were not subject to the objectives of the agrarian reform". ${ }^{22}$ It may be added that the 1958 Act with its Article 9 was still in force, which created a hermetic system for seizure of property, with practically no possibility to defend one's rights. A potential appeal against a decision based on Article 9 was of no use, since if the conditions for seizure

${ }^{21}$ M. Błażejczyk, Sadowa kontrola decyzji administracyjnych $w$ sprawach rolnictwa, "Nowe Rolnictwo" 1980, no. 20, p. 30.

${ }^{22}$ Decision of the District Court in Lublin of 14 December 2016, Ca 733/16, LEX no. 2196517. 
were observed - i.e. that the State was in possession of another person's agricultural or forestry property before 5 April 1958 and that did not come under the provisions of Article 9 (2) - the decision on seizure of the property would have to be issued and was legal. Indeed, the problem lay not in the application of the law, but in its content. Of course, there was a certain scope for reviewing decisions issued on the basis of Article 9. An example is the judgement of the Supreme Administrative Court in Wrocław of 15 November 1988 (SA/Wr 525/88, CBOSA), in which the Court found the decision based on Article 9 (1) to be invalid on the grounds that the seizure of the real estate belonging to owners on the basis of the Decree of 6 September 1951 on the protection and regulation of ownership of peasant farms in the Recovered Territories (Journal of Laws no. 45, item 340, as amended), who were engaged in agricultural production thereon. However, this was only a margin of the problem.

It is worth noting that by the Act of 26 March 1982 (therefore, during martial law) on the protection of agricultural and forest land, ${ }^{23}$ as many as four other legal bases for the compulsory seizure of agricultural land by the state were repealed under Article 51. These included, i.a., expropriation and deprivation of property on account of tax arrears. It was rightly noted that in this way "the sustainability of individual farms was strengthened". ${ }^{24}$ It can be added that the mentioned Article 51 marked the final capitulation of the communist state in the struggle for liquidation of individual ownership of land, because farmers obtained then real guarantees of inviolability of farms. However, characteristically, the discussed Article 9 of the 1958 Act was not repealed at that time. It was still the law in force and could be the basis for seizing agricultural or forestry property owned by the state before 5 April 1958. "The Act does not provide for any time limit within which the seizure of the property by the State shall take place. It can even be done after 20 years. From the point of view of stabilization of property relations this is not the most fortunate solution" - wrote S. Breyer prophetically in 1958..$^{25}$

Interestingly, the supporters of the view that the establishment of the Supreme Administrative Court was of crucial importance for the possibility of challenging the unlawful effects of the agrarian reform do not give any examples from the jurisprudence practice in relation to the decisions on the basis of the Agrarian Reform Decree or the 1958 Act. Thus, in the 1980s not only the political situation, but also the law in force still prevented the return of unlawfully seized agricultural and forest properties. Moreover, it is known that in the first decade the jurisdiction ratione materiae of the Supreme Administrative Court was enumerated (Article $196 \S 2$ of the Code of

23 Journal of Laws 1982, no. 11, item 79.

${ }^{24}$ R. Budzinowski, Przymusowe przejmowanie nieruchomości rolnych, Warszawa-Poznań 1985, p. 159.

${ }^{25}$ S. Breyer, Sprzedaż i przejmowanie nieruchomości rolnych przez państwo, "Nowe Prawo" 1958, no. 9 , p. 45. 
Administrative Procedure), and a significant extension of the scope of control exercised by the Supreme Administrative Court was possible only after the change of the political system of the state and was effected in 1990. The Supreme Administrative Court also ruled that: "Pursuant to Article $196 \S 2$ of the Code of Administrative Procedure, a decision of a state administrative body concerning an individual case may be appealed to the Supreme Administrative Court on the grounds of unlawfulness. The administrative act on the basis of which the real estate owned by Mr. W.G. was seized for the benefit of the State is not an administrative decision within the meaning of the Code of Administrative Procedure, but an act of general nature, which cannot be appealed against to the Supreme Administrative Court". ${ }^{26}$ Besides, it is known that the Supreme Administrative Court considered only complaints against administrative decisions issued in proceedings initiated after 31 January $1980 .{ }^{27}$ So did the Supreme Administrative Court stated: "Pursuant to Article 14 of the Act of 31 January 1980 on the Supreme Administrative Court and on amending the Code of Administrative Procedure Act, the provisions of the Code of Administrative Procedure on appealing to court against administrative decisions on the grounds that they are unlawful shall apply to decisions issued in cases in which proceedings were instituted after the entry into force of this Act, i.e. after 31 January 1980", ${ }^{28}$

The view of the date when the Supreme Administrative Court was established as the beginning of the running of the time limit for acquisitive prescription is - we note it for the sake of completeness of the argument - also repeated nowadays in the rulings of common courts. For example, in the decision of the District Court in Białystok of 16 June 2017, the opinion was presented that "after 1 September 1980, the actual possibility to challenge the decision of the Governor of 1949 to an independent court arose". ${ }^{29} \mathrm{We}$ consider this view to be erroneous in relation to cases in which Article 9 (16) of the 1958 Act could still apply.

\section{THE PROBLEM OF RESTITUTION OF AGRICULTURAL AND FOREST PROPERTIES AFTER 1989}

The change of political situation (but not of law) led very soon after 1989 to a veritable avalanche of claims for restitution of real estate or for equivalence and compensation for real estate seized under the agrarian reform and other acts of expropriation or confiscation of real estate. The barrier to the acceptance of these claims

\footnotetext{
26 Archive of Modern Records in Warsaw, Ministry of Justice, ref. no. 618, 1/72, p. 8.

27 Sprawozdanie Naczelnego Sądu Administracyjnego za okres od 1 IX do 31 XII 1980 r., Warszawa 1981, pp. 4-6.

${ }^{28}$ Archive of Modern Records in Warsaw, Ministry of Justice, ref. no. 618, 1/72, p. 8.

${ }^{29}$ Decision of the District Court in Bialystok of 16 June 2017, II Ca 321/17, LEX no. 2330694.
} 
was the still valid Article 9 of the 1958 Act. According to its letter, any claim, e.g. for a declaration of invalidity of the decision to take over real estate for the benefit of the agrarian reform, should have led to a decision to seize this real estate for state ownership. Hence, both the Ministry of Agriculture and the General Conservator of Monuments informed petitioners of the impossibility of recovering the property and sent petitioners back ad calendas graecas, i.e. informed them that their claims would be covered by the Reprivatisation Act. In order to simplify their task, both officials developed a blank form for a quick reply. The blank sheet of the Minister of Agriculture and Food reads: "In accordance with the provisions of the above-mentioned decree, land property owned or co-owned by natural or legal persons was subject to seizure for the benefit of the state if its total area exceeded 50 ha of agricultural land or 100 ha of general area. Palace-park and manor-park buildings were also subject to seizure as an integral part of the estate. The provisions of the aforementioned Decree from 6 September 1944 are still the applicable legal standard in this regard. Therefore, your request to recover the aforementioned estates with manor-park complexes cannot be taken into consideration in light of the legal norms currently in force. At the same time, the Ministry would like to point out that the change of the legal status binding in this respect may only be effected by passing a relevant act by the Parliament". ${ }^{30}$ On the other hand, the General Conservator of Monuments in his blank sheet sent applications for restitution of real estate to the Ministry of Agriculture, informed that he supports them and proposed the Minister to take a legislative initiative in order to "statutorily regulate the matter of restitution of historic properties to former owners (heirs) of these properties". ${ }^{31}$ In other words, both officials were in agreement that the legal status that persists as a remnant of the People's Republic of Poland does not give the former owners of the properties any possibility of effective revindication action.

Actions aimed at changing the situation, at least partially, were taken by the Ombudsman, Professor E. Łętowska. Probably in 1991, she addressed a letter to the Minister of Culture and Arts concerning the activities of state authorities in relation to restitution claims of former owners of palace-park complexes, or their successors, which had been seized on the basis of the Decree of 6 September 1944 on the implementation of agrarian reform. "In her letter to the Minister of Culture and Art, the Ombudsman asked for a position on the proposed policy of the Ministry in these matters. The standpoint taken by the Department, which until the issue is comprehensively regulated by the provisions on re-privatization, solutions should be sought

${ }^{30}$ Letter from the Director of the Department of Land Management and Agricultural Equipment of the Ministry of Agriculture and Food of 15 October 1990 to Olga Czartoryska, Archive of the Ministry of Agriculture and Rural Development, ref. no. 215/1, p. 81.

${ }^{31}$ Letter from the General Conservator of Antiquities of 14 August 1990 to J. Grzesik, Director of the Department of Land Management and Agricultural Equipment in the Ministry of Agriculture and Food, Archive of the Ministry of Agriculture and Rural Development, ref. no. 215/1, p. 75. 
in the provisions of the Act of 29 April 1985 on land management and expropriation of real estate, by transferring these properties to their owners or legal successors for the so-called symbolic zloty (Article 40 (4) of the said Act) is fully shared by the Ombudsman" - it was stated in the "Bulletin of the Ombudsman". ${ }^{32}$ This position meant that both state officials recognized the irreversibility of the transformations made by the agrarian reform and, in fact, made the owners an immoral offer of a repurchase. The price was not important here. It must be admitted that in many cases the owners and their heirs took advantage of such proposals. For example, the heirs of count Hieronim Tarnowski, the owner of the palace-park complex and the Rudnik estate, tired of trying to return the property, decided after several years to buy it back. ${ }^{33}$ "After all, even the post-communist governments did not treat the former landowners kindly" - writes Hieronim's grandson Andrew Tarnowski. ${ }^{34}$

An illustration of the complicated process of restitution of estates seized unlawfully on the basis of the Agrarian Reform Decree is the history of efforts made by the heiress to return the palace-park complex of Rozalin in the Nadarzyn municipality in Masovian Voivodeship. She was one of the first to start such efforts. In 1991, her attorney wrote a bitter complaint to Prime Minister J. Olszewski, calling the Ministry of Agriculture headed by G. Janowski, which was considering the restitution of the palace ownership, "the most communist of all ministries". The reason for such a term was that the Ministry calculated the area of agricultural land on the basis of a memorandum from 1948, when - as we know - the aim was to prove the largest possible area of agricultural land to be seized for the purposes of agrarian reform. ${ }^{35}$

We give examples of restitution activities after 1989 to show that even in the first years after the political transformation no restitution mechanisms were created. This fact confirms that, even more so in the 1980s, there were no possibilities of re-vindication, and invoking - on the counter-opinion - the allegedly improving situation of owners as a result of the Supreme Administrative Court activity is an example of a formalistic approach, detached from the realities of the People's Republic of Poland. Likewise, the lip service given in many judgements suggesting that after 4 June 1989, as if by magic, the legal situation changed and thus the time limits for acquisitive prescription started to run ${ }^{36}$ is not confirmed by any facts.

32 J. Majorowicz, A. Poczobutt-Odlanicki, Roszczenia rewindykacyjne i odszkodowawcze w związu z utrata własności nieruchomości jako przedmiot działalności Rzecznika Praw Obywatelskich, "Biuletyn RPO. Materiały" 1992, no. 14, p. 16.

33 A. Tarnowski, Ostatni mazur. Opowieść o wojnie, namiętności i stracie, Warszawa 2008, p. $381,387$.

34 Ibidem, p. 307.

${ }^{35}$ Letter of attorney Ryszard Grzesiuła to Jan Olszewski of 27 December 1991, Archive of the Ministry of Agriculture and Rural Development, ref. no. 968/2, p. 17.

36 See, e.g., Decision of the District Court in Kalisz of 9 September 2020, I NS 1169/19, non-published. From the justification (p. 20): "Although the indicated date is symbolic, it constitutes a histor- 


\section{ARTICLE 9 (16) OF THE 1958 ACT BEFORE THE CONSTITUTIONAL TRIBUNAL}

Shortly after the transformation of the political system, the Ombudsman, Professor E. Łętowska, realizing the lasting consequences of the provision, requested the Constitutional Tribunal on 12 October 1990 to adopt a resolution providing a universally binding interpretation of Article 16 (Article 9 of the former numbering) of the Act of 12 March 1958 on the sale of real estate of the State Land Fund and the arrangement of certain matters related to the implementation of agrarian reform and agricultural settlement (consolidated text, Journal of Laws 1989, no. 58, item 348). The Ombudsman asked for clarification of the legal issue, which raised doubts in the application of this provision and which was reduced to the question:

- are, in the light of Article 16 of the Act on taking over agricultural and forestry properties for state ownership, only the conditions mentioned in the aforementioned provision being decisive, i.e. a) the real estate being seized by the state prior to the date of entry into force of the Act, i.e. by 5 April 1958 , and b) the real estate continuing to be in possession of the state or being handed over by the state for use by other natural or legal persons irrespective of the circumstances under which the real estate was seized by the state,

- or whether that provision does not cover, and has not covered, situations in which the owner has expressed the will to recover his property or, for objective reasons beyond his control, has been unable to assert his rights. ${ }^{37}$

In the justification for her motion, the Ombudsman pointed out that in administrative practice, farms seizures took place as a result of an exclusively literal interpretation of this provision, disregarding other types of interpretation in the application of which rulings on the seizure of agricultural property for state ownership can and do raise objections (pp. 79-80). Giving examples of the literal application of the provision in the complaints to the Ombudsman, she suggested that the Court's interpretation should consider the systemic and purposive interpretation and accept, by way of a "cautious analogy", the existence of so-called "concealment" period, as in Article 34 of the Decree of 8 March 1946 on abandoned and formerly owned

ically tangible reference point from which it is possible to attribute to the non-possessing owners the duty to remain active in order to regain the property". See earlier approving views in the doctrine: I. Hasińska, op. cit., p. 89.

37 Wniosek RPO do TK z dnia 12 października $1990 \mathrm{r}$. o podjęcie uchwały zawierającej powszechnie obowiązującą wykładnię art. 16 (art. 9 dawnej numeracji) ustawy z dnia 12 marca $1958 \mathrm{r}$. o sprzedaży nieruchomości Państwowego Funduszu Ziemi oraz uporządkowaniu niektórych spraw związanych z przeprowadzeniem reformy rolnej i osadnictwa rolnego (tekst jedn. Dz. U. z $1989 \mathrm{r}$. Nr 58, poz. 348), „Biuletyn Rzecznika Praw Obywatelskich” 1990, no. 2-3, item 68b, pp. 76-82. Further in the main text we refer to this publication. 
by Germans property (Journal of Laws no. 13, item 87). This would allow, in the view of the Ombudsman, for the period from the seizure of the property by the State to 5 April 1958 (date of entry into force of the 1958 Act) to be regarded as a so-called "concealment" period. "In that case, any action taken by the owner to regain possession of the property would have to be regarded as an action rendering ineffective the seizure of the property by the State under Article 9 (16) of the Act in question. It seems that an analogous principle should apply to those persons who, for reasons beyond their control (e.g., absence in the country), could not in the indicated period take action to reclaim the property" (pp. 81-82).

The Ombudsman's request for an interpretation was in fact aimed at alleviating the negative effects of Article 9 of the Act, and was also supported by the Prosecutor General. However, the Constitutional Tribunal, in its resolution of 20 February 1991 (W. 5/90), gave a static, historical and linguistic interpretation to Article 9 (16) of the Act and held that the seizure of agricultural and forestry property into State ownership under Article 9 (16) of the 1958 Act was determined solely by the conditions listed in the cited provision, namely: taking possession of the property by the State prior to the date of entry into force of the Act, i.e. by 5 April 1958, and continued possession of the real property by the State or its transfer for use to other natural or legal persons - regardless of the circumstances under which the property was seized by the State. In accordance with the resolution of the Constitutional Tribunal, a real estate whose owners had expressed the will to reclaim their property prior to 5 April 1958, or had been unable to do so for objective reasons beyond their control, could also be taken over by the State. The Court did not accept the solution proposed in the Ombudsman's motion, as it stated that it went beyond the limits of interpretation and sought to make the application of Article 9 (16) subject to additional conditions not provided for in this or any other provision. The Court further inferred that "such a law-making interpretation cannot be justified even by the exceptional rigour of Article 16 of the Act in question, by means of which a number of private agricultural and forest properties were seized into the State's ownership without any compensation. Reparation of the harm done to citizens by that provision, which is contrary to the principles of social justice, may instead be the subject of statutory regulation, possibly in the form of the so-called reprivatization of agricultural and forestry property". 38

The Tribunal thus confirmed the interpretation of Article 9 (16) given by administrative bodies and courts in the People's Republic of Poland, recognizing it as consistent with the content of the law. It also admitted that the "exceptional rigour" of Article 9 did not give citizens any opportunity to defend their rights. The content of Article 9 (16) did not raise any doubts in the Court, which abstracted in

${ }^{38}$ Resolution of the Constitutional Tribunal of 20 February 1991, W. 5/90, OTK 1991, item 18 , pp. 186-193. 
its ruling from axiological assessments and, probably for opportunistic reasons, did not (admittedly, did not have to) express an opinion on the constitutionality of the provision. For the purpose of these considerations, however, the ruling of the Constitutional Tribunal is of fundamental importance, because it proves that as long as the provision in question was in force, the possibility of asserting any claims did not exist. The Court did not see any possibility of applying any interpretation that would mitigate the "excessive rigour" of the provision. Thus, from the point of view of the "people's" authorities, the provision adequately fulfilled its role.

\section{CONCLUSIONS}

As it is known, the resolution of the panel of 7 judges of the Supreme Court of 15 April $2015^{39}$ states that "the validity of Article 9 (3) and (4) of the Act of 12 March 1958 on the sale of state agricultural property and the regulation of certain matters related to the implementation of the agrarian reform and agricultural settlement (Journal of Laws no 17, item 71, as amended; Article 16 (3) and (4) in the consolidated text: Journal of Laws 1989, no. 58, item 348, as amended) did not constitute the reason for suspending the course of acquisitive prescription by the State Treasury of the properties covered by Article 9 (1) (Article 16 (1)) of that Act".

A panel of the Supreme Court adopted the view that the content of the resolution is supported by the fact that the Constitutional Tribunal did not pronounce on the constitutionality of Article 9 (16) and that the "allegation that the reason, in the nature of a suspension of the administration of justice or force majeure, excluding the course of the acquisitive prescription of real estate by the State Treasury may be the existence of a normative act, which creates the basis for seizure of such real estate by the State Treasury, would be marked by an obvious contradiction and would indirectly lead to undermining the normative force of this act".

In the light of the above historical arguments about the genesis and validity of Article 9 (16), one cannot agree with the content of this resolution. If we were to agree with it, it would have to be considered that the Supreme Court in 2015 sealed the system of unlawful seizures of land and forest properties, the system created since 1944. This system could not have been created without questioning the right to a trial, which is what the Supreme Court resolution in question leads to. It accepts a state of exclusion of the right to recovery and trover actions, with the simultaneous running of the acquisitive prescription time limit. The exclusion of the time limit of acquisitive prescription is practically the last - in our opinion - possibility to reverse unlawful consequences of unlawful acts of the state in the sphere of seizure of land and forest properties.

39 III CZP 82/14, LEX no. 1677788. 
It is characteristic that the Supreme Court excluded the course of acquisitive prescription in similar cases (in the opposite situation), when the interest of the State was involved. In a decision of 22 December $1966,{ }^{40}$ the Supreme Court held that the owner of real estate covered by an agrarian reform or nationalization of forests could not acquire ownership of that real estate by way of acquisitive prescription, even if he had kept it in his possession for the period stipulated in Article 172 of the Civil Code (Article 50 of the Property Law of 1946).

In the case at issue, the Supreme Court, as a result of an extraordinary review by the General Prosecutor of the People's Republic of Poland against the decision of the District Court in Starogard Gdański dated 20 February 1963, overruled the appealed decision and referred the case back to the District Court in Starogard Gdański for re-examination. The Supreme Court held that the assumptions underlying the nationalization legislation which led to the reconstruction of the agricultural system in the People's Republic of Poland stood in the way of the applicant acquiring ownership of this property through this procedure. This referred in particular to the provisions of the Polish Committee of National Liberation Decree of 5 September 1944 on carrying out agrarian reform and the Polish Committee of National Liberation Decree of 12 December 1944 on seizing certain forests for the property of the State Treasury. The Supreme Court held that due to the fundamental objective - from the point of view of the political system - of this legislation, it is impossible to assume that the former owner of the real property covered by the agrarian reform or nationalization of forests could, by retaining possession of the real property, counteract the reconstruction of the agricultural system by way of a civil law measure, i.e. acquisition of ownership by way of acquisitive prescription. On the contrary, the Court held that in such circumstances the former owner could not acquire its previous property by way of acquisitive prescription. The Court referred to a similar thought expressed in the resolution of the panel of 7 judges of the Supreme Court of 7 June 1962 (1 CO 11/62), already cited in this text. It referred to the interest of the People's Republic of Poland, connected with special protection of social property.

The above case demonstrates the ineffectiveness of attempts of acquisitive prescription of real estate taken over by the State. Despite the time lapse of almost 50 years between these judgements, it is impossible not to see that they are an expression of the same reasoning, based on Kali's way of understanding reality from the H. Sienkiewicz novel.

For reasons that are incomprehensible to us, the justification of the $2015 \mathrm{Su}-$ preme Court resolution, while presenting in great depth the previous case law of the Supreme Court, fails to mention the 1991 interpretation of the Constitutional Tribunal on the content of Article 9 (16). Perhaps this is the repercussion of an old

${ }^{40}$ III CR 309/66, OSNCP 1967, no. 6, item 114. 
competence dispute between the Supreme Court and the Constitutional Tribunal, but it cannot be ignored that the omission of the Constitutional Tribunal's interpretation made it easier for the Supreme Court to adopt the 2015 resolution. The decision of the full Constitutional Tribunal confirmed indeed that the provision of Article 9 (16) should have been interpreted in accordance with the intention of the communist legislator. This was happening a few months before the provision was deleted, after more than 43 years of having been force. "Excessive rigour" of this provision thus prevented wronged owners from claiming their rights during the entire period of its validity.

The discussed 2015 resolution of the Supreme Court was adopted in the specific atmosphere of the increasing number of opinions of influential lawyers that it is high time to close the way to assert claims arising from the agrarian reform. ${ }^{41}$ However, this resolution has been frequently challenged in the case law of common courts. For example, the above-cited ruling of the District Court in Bialystok of 27 April 2018 (II Ca 57/18) contains such criticism. A similar position is expressed in the decision of the District Court in Sieradz of 3 April 2019, which, with a very similar factual situation, completely rejected the argumentation of the Supreme Court expressed in the resolution and assumed that until the repeal of Article 9 (16), there was a state of suspension of justice, resulting in the fact that the time limits for acquisitive prescription did not run. ${ }^{42}$

We are of the opinion that in relation to the rights of owners harmed by the provisions of the legal acts on agrarian reform, the theses of the decision of the Supreme Court of 29 April 2010 remains valid: "2. For the purposes of protection against the State Treasury's acquisitive prescription of persons who lost their possession of real property in the previous period as a result of the State's sovereign action, force majeure should be understood as a state, independent of the owner, caused by political conditions, which is objective and of universal impact, of inability to effectively pursue the release of the real property by legal means. In order to determine the moment when the obstacle ceased to exist, it is crucial when its widespread impact ceased and when the owner was able to undertake actions aimed at reclaiming the property. However, it should be provided that the obstruction preventing the commencement or causing the suspension of the course of the acquisitive prescription should be objective in nature in the sense that the time when it arises and ceases is determined by objective circumstances, independent of the behaviour of the person affected by the obstruction. When making this assessment, it should be considered that the application of Article 121 (4) in conjunction with Article 175 of the Civil Code in the situations discussed is justified only when it

${ }^{41}$ E. Łętowska, Orzecznictwo sadowe jako instrument reprywatyzacji zdekoncentrowanej, [in:] Reprywatyzacja w orzecznictwie sadów, ed. M. Plilich, Warszawa 2016, pp. 89-90.

${ }^{42}$ Ca 71/19, LEX no. 26665744. 
has been established that a person is authorized to effectively pursue a claim for the release of real property was actually deprived of this possibility. Such a finding cannot be made solely on the basis of claims of the entitled person. This is important, as demonstrating these circumstances should prevent the danger of excessive subjectivisation in recognizing the state of force majeure. 3 . The prerequisites for suspending the course of the limitation period could, in a certain situation, be such legal regulations - not currently in force and unacceptable in a democratic state under the rule of law - that prevented effective measures from being taken to prevent the State Treasury from acquiring property by way of acquisitive prescription". ${ }^{43}$

Consequently, this study represents the view that the period in which both the Agrarian Reform Decree and the subsequent legal acts were in force, with particular emphasis on the period in which the 1945 Decree was in force (Journal of Laws no. 28, item 321) and then Article 9 (16) of the 1958 Act excluded the course of the acquisitive prescription in favour of the State Treasury of the agricultural and forestry properties unlawfully seized by the State. This period lasted until 31 December 1991, the final date of the validity of Article 9 (16).

In this context, the decision of the Supreme Court of 9 October 2015, made after the date of the resolution of the panel of 7 judges of the Supreme Court, should be recalled, which de facto undermines the main thesis of the resolution on the non-suspension of the time limit needed for acquisitive prescription. The decision contains a convincing argument about the high harmfulness of the factual state manifested in non-uniform, inconsistent jurisprudence. ${ }^{44}$ It is also worth quoting a later, i.e. made after the 2015 resolution, decision of the Supreme Court of 18 May 2017, ${ }^{45}$ in which the view was expressed that "a state of equal suspension of justice may in fact be referred to when the systemic conditions and the legal state not only made it impossible to pursue a claim due to the unavailability of legal remedies, but also when, due to the common practice of applying the provisions in force, there was no chance of obtaining a decision favourable to the entitled party".

Finally, when assessing the legal situation of owners wronged by the agrarian reform, one should remember about the role and tasks of courts in the People's Republic of Poland. Pursuant to Article 48 of the Constitution of the People's Republic of Poland, adopted by the Legislative Assembly on 22 July 1952 (Journal of Laws 1952, no. 33, item 232), courts were to guard the system of the People's Republic of Poland, protect the achievements of the Polish working people, uphold the rule of law, social property and citizens' rights, punish offenders (later Article 58 of the Constitution of the People's Republic of Poland, consolidated text, Journal of Laws 1976, no. 7, item 36).

${ }^{43}$ Decision of the Supreme Court of 29 April 2010, IV CSK 474/09, LEX no. 602730.

${ }_{44}$ Decision of the Supreme Court of 9October 2015, IV CSK 473/13, LEX no. 19225691.

${ }^{45}$ III CSK 221/17, LEX no. 2348534. 
Provisions of the Law on the Common Court System defined the courts supreme tasks in a slightly different manner. Article 2 of the Regulation of the President of the Republic of Poland of 6 February 1928 - Law on the organization of common law courts, ${ }^{46}$ in force until the end of August 1985, specified that the administration of justice in the People's Republic of Poland was to protect: a) the system of people's democracy and its development towards socialism; b) social property and the rights and interests of state institutions, co-operatives, state and co-operative enterprises and social organisations; c) the personal and property rights and interests of citizens guaranteed by the people's legal order.

It should be noted that para. c) referred not to all citizens' rights, but only to those "guaranteed". In addition, according to Article 3 of the Law on the Common Court System, the courts of the People's Republic of Poland were to educate citizens in the spirit of loyalty to the People's Republic of Poland, compliance with the principles of the People's Rule of Law, work discipline and care for social property.

The new Act - Law on the Common Court System, adopted on 20 June 1985, ${ }^{47}$ which came into force on 1 September 1985, specified in Article 3 that the task of common courts was to protect the legal order, and in particular: the political and socio-economic system of the People's Republic of Poland; social property; rights and legally protected interests of state institutions and enterprises, cooperatives and social organizations of the working people; personal, family and property rights and interests of citizens protected by law.

In addition, in Article $4 \S 1$ of the Law on Common Court System, the so-called principle of educational influence of the courts was maintained. The provision reads: "In carrying out the administration of justice, the common courts should have an educational impact in terms of compliance with the principles of the rule of law, social justice, work discipline, care for social property and prevention of violations of the law, in accordance with the principles and objectives of the system of the Polish People's Republic".

The not published decision of the Supreme Court of 19 March 2021 (IV CSK 479/20) cites other not published decisions, according to which the Supreme Court has no uniform view on the problem if the petition to annul the decision about taking over the property interrupts the time required by law to gain the acquisitive prescription. ${ }^{48}$ It would seem that the petition interrupts the time, but a contrary view is presented also in jurisprudence. This makes more difficult for owners to

46 Journal of Laws 1964, no. 6, item 40, as amended.

47 Journal of Laws 1985, no. 31, item 137.

48 Decision of the Supreme Court of 18 April 2018, IV CSK 55/18, non-published; decision of the Supreme Court of 31 September 2018, I CSK 302/18, non-published; decision of the Supreme Court of 4 January 2019, IV CSK 265/18, non-published; decision of the Supreme Court of 17 July 2020, III CSK 9/18, non-published; decision of the Supreme Court of 1 October 2020, III CSK 62/20, non-published. 
regain the property from the State Treasury. Finally, we have to agree with G. Tracz that the state of at least 20 years of discrepancies in jurisprudence as to the date of commencement of the time limit required for acquisitive prescription (1980-1991) is an undesirable phenomenon, which requires the adoption of a uniform court position. ${ }^{49}$ We may add that it is a state which ridicules the judiciary. Our standpoint remains unchanged after the latest (i.e. from 2021) amendment to the Code of Administrative Proceedings, which introduced 30-year period for annulment of administrative decision.

\section{REFERENCES}

\section{Literature}

Bereza A., Sad Najwyższy w latach 1945-1962. Organizacja i działalność, Warszawa 2012.

Błażejczyk M., Sąowa kontrola decyzji administracyjnych w sprawach rolnictwa, "Nowe Rolnictwo" 1980, no. 20.

Breyer S., Sprzedaż i przejmowanie nieruchomości rolnych przez państwo, "Nowe Prawo" 1958, no. 9. Budzinowski R., Przymusowe przejmowanie nieruchomości rolnych, Warszawa-Poznań 1985.

Fiedorczyk P., Polski Październik a reforma rolna, "Z Dziejów Prawa” 2019, vol. 12(20), DOI: https://doi.org/10.31261/ZDP.2019.20.45.

Hasińska I., Z procesowej problematyki wywłaszczenia na tle dekretu PKWN o przeprowadzeniu reformy rolnej z 6 września 1944 r., "Studia Iuridica Lublinensia" 2017, vol. 26(1),

DOI: https://doi.org/10.17951/sil.2017.26.1.77.

Korzeniewska-Lasota A., Państwo, właściciele i ich spadkobiercy wobec mienia pozostawionego przez obywateli polskich $w$ województwach wschodnich międzywojennej Rzeczypospolitej. Studium historyczno-prawne, Gdańsk 2018.

Łętowska E., Orzecznictwo sadowe jako instrument reprywatyzacji zdekoncentrowanej, [in:] Reprywatyzacja w orzecznictwie sądów, ed. M. Plilich, Warszawa 2016.

Machnikowska A., Prawo własności w Polsce w latach 1944-1981. Studium historycznoprawne, Gdańsk 2010.

Majorowicz J., Przebudowa ustroju rolnego Polski Ludowej w orzecznictwie Sądu Najwyższego, [in:] Sesja dwudziestolecia Sądu Najwyższego w Polsce Ludowej w dniach 8-10 grudnia 1966 r. Materiaty, Warszawa 1967.

Majorowicz J., Poczobutt-Odlanicki A., Roszczenia rewindykacyjne i odszkodowawcze w zwiazku z utrata własności nieruchomości jako przedmiot działalności Rzecznika Praw Obywatelskich, "Biuletyn RPO. Materiały" 1992, no. 14.

Mazur M., Uwagi ogólne o sytuacji prawnej po Wyzwoleniu, [in:] Sesja dwudziestolecia Sadu Najwyższego w Polsce Ludowej w dniach 8-10 grudnia 1966 r. Materiaty, Warszawa 1967.

Prutis S., Reformy agrarne w Polsce po odzyskaniu niepodleglości w 1918 roku, "Studia Iuridica Agraria” 2018, vol. 15, DOI: https://doi.org/10.15290/sia.2017.15.14.

Sprawozdanie Naczelnego Sadu Administracyjnego za okres od 1 IX do 31 XII 1980 r., Warszawa 1981. Stawarska-Rippel A., O instrumentalnym wykorzystywaniu prawa-ustrój polityczny i gospodarczy w orzecznictwie Sądu Najwyższego pierwszych lat Polski Ludowej, [in:] Prawo i czas. Ksiega

${ }^{49}$ G. Tracz, op. cit., p. 28. 
jubileuszowa z okazji 80-lecia urodzin Profesora Adama Lityńskiego, eds. M. Borski, D. Fleszer, A. Pokora, A. Rogacka-Łukasik, Sosnowiec 2020.

Stawarska-Rippel A., O ludowym prawie karnym w kontekście przeprowadzenia i zabezpieczenia skutków tak zwanej reformy rolnej z pierwszych lat Polski Ludowej, "Z Dziejów Prawa” 2019, vol. 12(20), DOI: https://doi.org/10.31261/ZDP.2019.20.41.

Stawarska-Rippel A., Prawo sadowe Polski Ludowej a prawo Drugiej Rzeczypospolitej 1944-1950, Katowice 2006.

Stokowski M.P., Odpowiedzialność Skarbu Państwa za przejęcie nieruchomości rolnych na mocy dekretu o przeprowadzeniu reformy rolnej na przykładzie majątku Lubowicz Wielki, "Miscellanea Historico-Iuridica" 2020, vol. 19(2), DOI: https://doi.org/10.15290/mhi.2020.19.02.19.

Tarnowski A., Ostatni mazur. Opowieść o wojnie, namiętności i stracie, Warszawa 2008.

Tracz G., Sytuacja prawna byłych właścicieli nieruchomości ziemskich w III Rzeczypospolitej, "Forum Prawnicze" 2016, no. 4.

\section{Archives}

Archive of Modern Records in Warsaw, Ministry of Agriculture and Agricultural Reforms, ref. no. 446.

Archive of Modern Records in Warsaw, Ministry of Justice, ref. no. 618.

Letter of attorney Ryszard Grzesiuła to Jan Olszewski of 27 December 1991, Archive of the Ministry of Agriculture and Rural Development, ref. no. 968/2, p. 17.

Letter from the Director of the Department of Land Management and Agricultural Equipment of the Ministry of Agriculture and Food of 15 October 1990 to Olga Czartoryska, Archive of the Ministry of Agriculture and Rural Development, ref. no. 215/1, p. 81.

Letter from the General Conservator of Antiquities of 14 August 1990 to J. Grzesik, Director of the Department of Land Management and Agricultural Equipment in the Ministry of Agriculture and Food, Archive of the Ministry of Agriculture and Rural Development, ref. no. 215/1, p. 75.

\section{Others}

Wniosek RPO do TK z dnia 12 października 1990 r. o podjęcie uchwały zawierającej powszechnie obowiązującą wykładnię art. 16 (art. 9 dawnej numeracji) ustawy z dnia 12 marca $1958 \mathrm{r}$. o sprzedaży nieruchomości Państwowego Funduszu Ziemi oraz uporządkowaniu niektórych spraw związanych z przeprowadzeniem reformy rolnej i osadnictwa rolnego (tekst jedn. Dz. U. z 1989 r. Nr 58, poz. 348), „Biuletyn Rzecznika Praw Obywatelskich” 1990, no. 2-3, item 68b.

\section{Legal acts}

Act of 12 March 1958 on the sale of state-owned agricultural property and on the regulation of certain matters relating to the implementation of agrarian reform and agricultural settlement (Journal of Laws 1958, no. 17, item 71, as amended).

Act of 26 March 1982 on the protection of agricultural and forest land (Journal of Laws 1982, no. 11, item 79).

Act of 20 June 1985 - Law on the system of common courts (Journal of Laws 1985, no. 31, item 137). Regulation of the President of the Republic of Poland of 6 February 1928 - Law on the organization of common law courts (Journal of Laws 1964, no. 6, item 40, as amended). 


\section{Case law}

Decision of the Constitutional Tribunal of 28 November 2001, OTK 2001, no. 8, item 266.

Decision of the District Court in Bialystok of 16 June 2017, II Ca 321/17, LEX no. 2330694.

Decision of the District Court in Bialystok of 27 April 2018, II Ca 57/18, LEX no. 2505911.

Decision of the District Court in Lublin of 14 December 2016, II Ca 733/16, LEX no. 2196517.

Decision of the District Court in Sieradz of 3 April 2019, Ca 71/19, LEX no. 26665744.

Decision of the District Court in Kalisz of 9 September 2020, I NS 1169/19, non-published.

Decision of the Supreme Court of 22 December 1966, III CR 309/66, OSNCP 1967, no. 6, item 114.

Decision of the Supreme Court of 29 April 2010, IV CSK 474/09, LEX no. 602730.

Decision of the Supreme Court of 9October 2015, IV CSK 473/13, LEX no. 19225691.

Decision of the Supreme Court of 18 May 2017, III CSK 221/17, LEX no. 2348534.

Decision of the Supreme Court of 18 April 2018, IV CSK 55/18, non-published.

Decision of the Supreme Court of 31 September 2018, I CSK 302/18, non-published.

Decision of the Supreme Court of 4 January 2019, IV CSK 265/18, non-published.

Decision of the Supreme Court of 17 July 2020, III CSK 9/18, non-published.

Decision of the Supreme Court of 1 October 2020, III CSK 62/20, non-published.

Judgement of the Supreme Administrative Court in Wrocław of 15 November 1988, SA/Wr 525/88, CBOSA.

Judgement of the Supreme Court of 29 September 1959, 1 CR 689/59, OSN of the Civil Chamber and Criminal Chamber 1960, no. 4, item 108.

Resolution of the panel of 7 judges of the Supreme Court of 13 October 1951, C 427/51, OSN 1953, no. 1 , item 1 .

Resolution of the panel of 7 judges of the Supreme Court of 15 April 2015, III CZP 82/14, LEX no. 1677788 .

Resolution of the Constitutional Tribunal of 20 February 1991, W. 5/90, OTK 1991, item 18.

\section{ABSTRAKT}

Przedmiotem rozważań w artykule są te stany faktyczne, które wystąpiły na gruncie dekretu o reformie rolnej i dotyczyły bezprawnego przejęcia przez Państwo zespołów pałacowo-parkowych. Dopiero po upadku realnego socjalizmu właściciele lub ich następcy prawni uzyskiwali stwierdzenie nieważności decyzji o przejęciu majątku. Był i jest to jednak dopiero początek zmagań, gdyż Skarb Państwa lub jego następcy prawni powołują się przed sądami powszechnymi na zasiedzenie nieruchomości objętej żądaniem zwrotu. Rozbieżność co najmniej 20 lat w orzecznictwie co do daty rozpoczęcia biegu terminu wymaganego do zasiedzenia (1980-1991) jest zjawiskiem niepożądanym, wymagającym przyjęcia jednolitego stanowiska sądów. Konsekwentnie autorzy niniejszego artykułu reprezentują pogląd, że okres obowiązywania zarówno dekretu o przeprowadzeniu reformy rolnej, jak i późniejszych aktów prawnych, ze szczególnym uwzględnieniem okresu obowiązywania dekretu z 1945 r. (Dz.U. nr 28, poz. 321) i następnie art. 9 (16) ustawy z 1958 r., wyłączał bieg zasiedzenia na rzecz Skarbu Państwa przejętych przez Państwo bezprawnie nieruchomości rolnych i leśnych. Okres ten trwał do 31 grudnia 1991 r., czyli do końcowej daty obowiązywania art. 9 (16).

Słowa kluczowe: zasiedzenie nieruchomości; reforma rolna; zespoły pałacowo-parkowe; Skarb Państwa; majątek; dekret o przeprowadzeniu reformy rolnej 